\title{
CZU: 581.522.4:634.15:58.006 (478) \\ https://doi.org/10.53040/gppb7.2021.65 \\ PERSPECTIVA CULTIVĂRII SPECIEI Mespilus germanica L. ÎN GRĂDINA BOTANICĂ NAȚIONALĂ (INSTITUT) „ALEXANDRU CIUBOTARU”
}

\author{
Mîtu Vitalie, Roșca Ion, Onica Elisaveta, Cutcovschi-Muștuc Alina \\ Grădina Botanică Națională (Institut) „,Alexandru Ciubotaru”, Chișinău, Republica Moldova \\ e-mail: alinacutcovschi@mail.ru
}

\begin{abstract}
This article describes the bioecological peculiarities of growth and development of the taxon Mespilus germanica L. in the "Alexandru Ciubotaru" National Botanical Garden (Institute).

Key words: Mespilus germanica L., growth, development, cultivation.

\section{Introducere}

Modernizarea asortimentului de plante cultivate, prevede introducerea și cultivarea noilor taxoni prețioși, contribuind direct la rezolvarea programului alimentar și de asanare a populației țării. Condițiile pedoclimatice ale republicii favorizează introducerea și cultivarea arbuștilor fructiferi netradiționali. Aceștia fiind nepretențioși la factorii mediului ambiant, nu cer îngrijiri speciale, tratări sanitare și pot fi utilizați în diferite ramuri ale economiei naționale. Cultura arbuștilor fructiferi netradiționali se extinde foarte repede în ultima perioadă de timp în R. Moldova. Agricultorii au conștientizat, că cultivarea arbuștilor fructiferi pe suprafețe mici pot aduce venituri net superioare comparativ cu cele obținute din valorificarea culturilor agricole tradiționale. Sortimentul de arbuști fructiferi bine cunoscut (zmeurul, coacăzul, murul, căpșunul) poate fi mobilizat, diversificat și îmbogățit cu zeci de taxoni noi, fructele cărora sunt adevărate depozite de substanțe biologic active și pot servi ca materie primă pentru industria alimentară și farmaceutică. Unul din acești arbuști prețioși este Mespilus germanica L. - moșmonul comun care aparține subfamiliei Maloideae C.Weber a familiei Rosaceae Juss. Genul Mespilus L. conține o singură specie - Moșmonul comun. Cele mai apropiate specii sunt din genurile Sorbus L., Crataegus L., Amelanchier Medik., Aronia Medik. În pofida faptului că moșmonul comun se cultivă de mii de ani, mai cu seamă în țările Caucazului și Orientului Apropiat, soiuri de moșmon comun nu sunt înregistrate, dar se cultivă cultivarul 'Macrocarpa', cu frunzele mai mari, de 10-12 cm și fructele de 3-5 cm. Sunt cunoscuți câțiva hibrizi de moșmon comun cu păducelul: Crataegomespilus grandiflora - hibrid între moșmonul comun și păducelul spinos (Mespilus germanica x Crataegus oxyacantha) și Crataegomespilus dardarii, hibrid între moșmonul comun și păducelul monogin (Mespilus germanica x Crataegus monogyna). Moșmonul comun are arealul în Caucaz, Iran, Asia Mică - sudul și sud-estul. Se ridică în munți până la 2000 m și crește pe malul mării Caspice. Crește în păduri rărite de stejar cu carpen în condiții de sol reavăn și destul de fertil, deseori formând desișuri la lizieră. În Republica Moldova foarte rar este întâlnit în parcurile vechi, se cultivă în Grădina Botanică Națională (Institut) „Alexandru Ciubotaru” (în continuare GBNI), Dendrariul și uneori în grădinile private $[2,4]$. În România, este introdus în cultură și crește sporadic subspontan în regiunea dealurilor. S-a adaptat și s-a sălbăticit în Crimeea (țărmul Mării Negre), Georgia, Armenia, Azerbaidjan [6].
\end{abstract}

\section{Materiale și metode}

În calitate de material vegetal de studiu au servit exemplarele de Mespilus germanica L., care cresc și fructifică în colecția de plante netradi'ionale din cadrul GBNI. Cercetările se efectuează în pepiniera de introducție a laboratorului de Dendrologie în cadrul proiectului de cercetare 20.80009.7007.19 „Introducerea și elaborarea tehnologiilor de multiplicare și cultivare prin tehnici convenționale și culturi in vitro a speciilor de plante lemnoase noi".

În literatura de specialitate se menționează dificultatea reproducerii prin semințe a moșmonului din cauza durabilităţii acestora $[1,3,5]$. Testând mai multe metode am evidențiat procedeele mai eficace.

Formele prețioase s-au multiplicat prin marcotaj și altoire pe portaltoi de păducel, păr, gutui sau puieți generativi de moșmon comun. Puieții obținuți generativ și vegetativ au fost repicați după prima perioadă 
de vegetație în containere pentru creștere suplimentară și la finele anului doi de vegetaţie au fost plantaţi în terenul permanent.

Observațiile fenologice s-au efectuat conform metodei elaborate de Grădina Botanică din Moscova [7] și perfectată de dr. hab. A. Palancean [2].

\section{Rezultate și discuții}

Moşmonul comun este cunoscut din antichitate, în sud-vestul Asiei și Europei, datorită fructelor sale delicioase, fiind menționate și în versurile lui William Shakespeare, care seamănă cu un măr sau o prună, iar alții o apreciază ca o combinație dintre măr și măceș. A fost foarte răspândit în trecut, dar de la an la an devine tot mai rar utilizat ca plantă fructiferă, preponderent cu scop decorativ.

La Casele Regale europene, moșmonul a fost un fruct foarte apreciat, deoarece însoțea cele mai bune vinuri, iar bucătarii francezi asociau gustul acestuia cu produse scumpe ,gourmet”, cum ar fi ciupercile, trufele sau caviarul.

Fructele, de culoare brun-roșiatică, de 2-4 cm, sunt adevărata comoară a moșmonului. Gustul fructelor de moșmon este dulce acrișor, ele conțin substanțe active importante: până la $10 \%$ glucide, 2,59 \% substanţe tanante, pectine până la $12 \%$, un procent scăzut de apă (60-70 \%), mucilagii, acid citric, malic și tartric, potasiu, zaharuri, proteine, săruri minerale, celuloză. Moşmoanele sunt fructe tonice, diuretice și au capacitatea de a regla tranzitul intestinal. Sunt recomandate pentru ameliorarea gutei (elimină uraţii), a reumatismului, tratarea faringitei, diareii, colitelor și litiazei renale. Ceaiul de moșmon este bogat în beta-caroten, vitamina $\mathrm{B}_{1}, \mathrm{C}$, calciu și fier. Este foarte bun remediu pentru ficat, rinichi și ameliorarea văzului [8].

Moșmoanele au efecte terapeutice asupra stomacului, intestinelor, sunt benefice în tratarea reumatismului, tulburărilor respiratorii, contribuie la cicatrizarea rănilor și refacerea mucoaselor gastrice și previn infarctul miocardic.

Fructele de moșmon sunt foarte rezistente la temperaturi scăzute, și pot fi culese abia după ce dă prima brumă, în caz că sunt culese mai devreme, sunt foarte tari și astringente. Fructele coapte în anotimpul iernii dezvoltă arome complexe, unice, rămânând pe plantă după ce frunzele au căzut și a dat înghețul, se înmoaie, capătă o aromă plăcută și o culoare asemănătoare cu cea a zahărului brun. Fructele culese mai devreme trebuie păstrate în lădițe acoperite cu fân până se coc bine. Ele se înmoaie, devin comestibile la 3-4 săptămâni de la recoltare (prin noiembrie-decembrie). Sunt ideale ca fructe de iarnă și pot fi păstrate până în primăvară dacă sunt depozitate în camere reci la loc întunecat, în beciuri. Excelent desert de iarnă, fiind prăjit în unt cu cuișoare, alături de brânzeturi fine, ciuperci, trufe sau caviar. Fructele pot fi consumate crude, decojite, prăjite în unt cu cuișoare sau preparate în diverse rețete de compot, dulceață, bomboane, torte, băuturi răcoritoare sau sirop.

Semințele pot fi valorificate sub formă de pulbere ce poate fi consumată în vin alb și ajută la combaterea gutei. Fructele se pot marina.

Ramurile conțin aldehide și acizi organici. Frunzele sunt bogate în glucide, acizi organici și derivați ai acestora, flavonoizi. Din frunze se extrage o substanță, care se utilizează în cosmetică și medicină împotriva alopeciei ce ajută la creșterea părului. Cercetările contemporane au demonstrat, că extractul din frunzele moșmonului inhibă creșterea celulelor canceroase, dar trebuie utilizat cu avizul și sub controlul medicului [8].

Infuzia preparată din rădăcină, scoarță sau frunze se utilizează în cazul inflamațiilor maligne. Scoarța și frunzele, fructele și semințele macerate se pot folosi în cazul diareii, dizenteriei. Infuzia de frunze se poate folosi în cazul bolilor de rinichi, aparatului respirator, hemoroizilor sau la clătitul faringelui în caz de inflamație. Mespilus germanica L. poate servi ca materie primă pentru industria alimentară, farmaceutică și ca sursă de hrană pentru fauna pădurii, plantă meliferă și decorativă. Moșmonul comun este o plantă cu calităţi ornamentale, mai ales în perioada înfloririi, fructificării, toamna târziu și iarna cu fructele rămase pe ramuri, utilizată pentru amenajările peisagistice. Frunzele și coaja conținând multiple substanțe tanante pot fi utilizate la tăbăcirea pielei. Lemnul este uşor, se lustruiește frumos și este accesibil la prelucrare în atelierele de strungărie pentru confecționarea obiectelor fine, suvenirelor.

Mespilus germanica L este un arbust de talie mare, care mai des crește în formă de arbore mic, până la 3-5 m. Tulpina scurtă, strâmbă și cu ramuri răsucite. Lemnul dur, compact, roșcat, cu pete medulare. Scoarța cenușie, cu crăpături nu prea adânci, se exfoliază în plăci. Coroana globuloasă, abundent foliată. Lujerii muchiați 
pubescenți, brahioblastele spinoase. Mugurii alterni, bruni, cu numeroși solzi păroși. Lujerii anuali ating maturitatea în lunile VII -VIII. Frunzele alterne, de 6-12 cm lungime și $4 \mathrm{~cm}$ lățime, eliptice, acute sau obtuze, groase și pubescente pe ambele fețe, pețiolul scurt de 0,5-1,0 cm lungime. Stipele sunt ovate și caduce. Frunzele și scoarța sunt astringente, conţinând tanine. Începutul perioadei de vegetaţie este martie - începutul lunii aprilie. Înfrunzirea are loc în aprilie-mai. Colorarea frunzelor - în septembrie-octombrie, iar căderea în octombrie-noiembrie. Perioada de la începutul vegetației până la înflorire constituie circa 30 zile. Mugurii florali se formează pe lăstarii în creștere din anul curent, cu excepția celor axiali, vegetativi. Desfacerea mugurilor florali începe în luna mai și durează circa o lună. Florile hermafrodite, solitare, aproape sesile sunt amplasate terminal pe lujerii scurți. Sepalele lanceolate sunt mai lungi ca petalele. Corola de 3-5 cm în diametru, petalele albe. Stamine numeroase, gineceul din ovar 5-carpelar cu 5 stile. Nectarul are culoarea scorțișoarei. Polenizarea - de albine. Fructele rotunde false, poame piriforme, de $2-3 \mathrm{~cm}$ (la formele de cultură $5-7 \mathrm{~cm}$ ), de culoare verde maculat, mai târziu brună sau brun-roșiatică, pulpa brunie, la vârf cu sepale persistente, lungi, îndreptate în sus. Masa a 100 fructe este de $700 \mathrm{~g}$. Mezocarpul conține sclereide, care se înmoaie la un timp după maturarea fructului. În anii cu toamne timpurii, fructele devin comestibile după primele înghețuri. Fructul conține 5 semințe tari. Masa a 100 de semințe este 140-170 g, într-un kg sunt circa 7 mii de semințe. Fructele sunt ideale pentru decorarea platourilor cu fructe de iarnă.

Moșmonul în primele perioade de vegetație crește repede, plantele la vârsta de 6 ani ating înălțimea până la 2,5-3,0 m, apoi cu vârsta scade din viteza de creștere, iar longevitatea este de circa 100 ani. Semințele se pregătesc pentru semănat după primele înghețuri, deoarece fructele devin moi și ușor se strivesc sau se tratează cu soluție de $0,01 \% \mathrm{KMnO}_{4}$ și se seamănă direct în sol îndată după recoltare, în așa mod germinează uniform în primăvara anului următor. Neavând posibilitate de a semăna toamna atunci semințele curăţate necesită o stratificare îndelungată - 15 luni și se seamănă în anul al doilea, în februarie-martie. În condițiile noastre varianta optimă a fost semănăturile de toamnă cu semințe proaspăt curățate, tratate cu soluție de $0,01 \% 24$ ore, apoi încorporate în sol bine afânat la o adâncime de $2-3 \mathrm{~cm}$. Procentul de germinație a semințelor a constituit 55-60 \% și corelează direct cu condițiile climatice în perioada de la încorporare și până la germinare, precum și cu respectarea tehnologiei pe toată perioada. În primul an puieții obținuți din semănăturile de toamnă ajung în înălţime la $10 \mathrm{~cm}$ și sunt repicaţi în containere pentru fortificare. În a doua perioadă de vegetaţie ating înălțimea de 40-50 cm și sunt apți de plantat la locul destinat. Procentul de prindere a puieților a constituit 85-90 \%, cu vârsta procentul de prindere se reduce. Norma de semănare este de $30 \mathrm{~g}$ la metru liniar. Greutatea medie a 1000 de semințe uscate este 130-165 g. Moșmonul comun este rezistent la geruri, la condițiile iernării și chiar la secetă. Înflorirea târzie dă posibilitatea ca florile să nu fie afectate de la înghețurile târzii de primăvară și obținerea unui randament înalt de concepție a fructelor. Aproape fiecare floare leagă fructe. Preferă soluri destul de fertile, formate pe substrat silicios. Nu vegetează bine pe soluri uscate, argiloase ori puternic calcaroase. Rezistent la umbră, dar preferă terenuri mai deschise cu expoziție luminoasă, unde fructificarea este mai abundentă, iar fructele mai calitative.

Deși cunoscut de secole, moșmonul nu prea a atras atenția populației, dar acum este în trend ascendent, trecând din livezile private în plantaţii comerciale în Europa. Înființarea unei plantaţii trebuie să respecte următoarele etape: analiza solului, pregătirea terenului și plantarea. Moșmonul preferă soluri profunde, permeabile, reavăne. Solul bine afânat favorizează dezvoltarea fasciculată a rădăcinii și are impact pozitiv asupra dezvoltării sistemului radicular. Plantarea se efectuează toamna sau primăvara devreme, când solul nu este înghețat sau îmbibat cu apă. Schema plantării în plantații comerciale poate fi de 4 x 4 ori 4 x 3, în rând poate fi redusă distanța. Plantele crescute în containere, pot fi plantate în orice perioadă a anului, dar totuși este de dorit nu în perioada activă de creștere, cu respectarea tehnologiei de cultivare. Se recomandă pregătirea unei mocirle din îngrășăminte organice, pământ și apă în care se moaie rădăcina fasonată pentru a ajuta cauterizarea rănilor și stimularea creșterii sistemului radicular. Recomandate pentru plantare sunt plantele de 2-3 ani. Infloresc și leagă fructe la trei ani, iar din al 4-lea an se poate vorbi despre producție, iar din anul al 6-lea se obțin recolte bogate. Asemenea pomilor de măr, moșmonul trebuie curăţat iarna pentru a avea o formă deschisă. Plantele tinere necesită tăierea vârfurilor pentru înlăturarea mugurilor de floare, ca să se dezvolte o coroană bine formată. Plantele mature nu au nevoie de tundere, îndepărtarea ramurilor uscate, deteriorate și, după necesitate, de rărire.

Fructele de moșmon se lasă pe plante la maxim cât permit temperaturile, de obicei până în noiembrie. Recoltarea se face cu condiția pentru a se păstra fructele până în primăvară. 
În general, moșmonul comun nu are probleme cu bolile și dăunătorii, deoarece este o plantă semisălbatică, însă uneori poate apărea rugina și focul bacterian, dar care nu provoacă daune majore. Pentru a avea o plantație cu regim fitosanitar bun se recomandă ca toamna târziu plantele tinere, până la înregistrarea temperaturilor negative, să fie tratate cu zeamă bordeleză, după care la trei zile se aplică ulei horticol care înfășoară scoarța și distrug potențialii dăunători rămași pe plantă. În primăvară procedura se repetă pentru profilaxia bolilor și dăunătorilor.

\section{Bibliografie}

1. ILIESCU, ANA-FELICIA. Cultura arborilor și arbuștilor ornamentali. București, Ceres 2008,422 p.

2. PALANCEAN, A. Dendroflora cultivată a Republicii Moldova. Chişinău, 2017, 327 p.

3. PALANCEAN, A. Reproducerea speciilor lemnoase. Chișinău. „Print-Caro”, 2013, 72 p.

4. PALANCEAN, A., COMANICI, I. Dendrologie (Asortimentul de arbori, arbuști și liane pentru împăduriri și spații verzi). Chișinău, Tipografia Centrală, 2009, 519 p.

5.ГАРТМАН, Х. Г., КЕСТЕР, Д. Е., Размножение садовых растений. Перевод с английского. Москва. 1963. $470 \mathrm{c}$.

6. Деревья и кустарники СССР. Изд-во АН СССР. М.-Л. 1954.Т. 3. с.511 -514.

7. Методика фенологических наблюдений в ботанических садах СССР. Бюл. ГБС.АН СССР. М. Наука.1979. Вып.113. с.3-8.

8. Растительные ресурсы СССР. Л. Наука. 1987. Т.3. С. 53 -54. 